\title{
Impact of Conservation Planning and Implementations on Cultural Heritage Values in the Historic Urban Site of Kuşadası
}

\author{
Elif Ece Yönetken-Candan ${ }^{1 *}$, Mine Hamamcıoğlu-Turan² \\ 1 Oikos Architecture \& Restoration, Aksoy Neighbourhood, Cemal Gürsel Street No. 386/2, 35590 Karşıyaka, Izmir, Turkey \\ 2 Department of Architectural Restoration, Faculty of Architecture, Izmir Institute of Technology, İzmir - Çeşme Street, Gülbahçe, \\ 35430 Urla, İzmir, Turkey \\ * Corresponding author, e-mail: eyonetken@gmail.com
}

Received: 03 January 2021, Accepted: 02 November 2021, Published online: 16 December 2021

\begin{abstract}
The study aims to evaluate the impact of the conservation planning and implementations on the cultural heritage values in a cultural landscape: Kuşadası, Aydın, Turkey. The study is limited to the decisions published on the Internet: decisions between 2013 and 2016. The methodology includes literature research, archive research in the related Regional Commission on the Conservation of Cultural Property, the Regional Directorate of Foundations, and the local administration. A site survey comprehending base map revision and photographic documentation, visual analysis, historical research and comparative study, and evaluation of conservation activities regarding concepts of conservation is also part of the research. As a result, conservation issues stem from inappropriate conservation implementations threatening the integrity of cultural heritage. The majority of the conservation implementations have focused on a single building scale. Unlicensed constructions stemming from insufficient control by the local administration in the historic urban environment and the lack of implementation of the conservation plan to remove inharmonious buildings and masses threatening the integrity of the urban layout. Preparation of a management plan, revision of the twenty-five-year-old conservation plan, and determination in their application are considered as indispensable for sustaining authenticity and integrity.
\end{abstract}

Keywords

historic urban site, cultural landscape, conservation, implementation, Kuşadası

\section{Introduction}

Turkey's legal framework for conservation is strongly organised. According to the conservation act of cultural heritage numbered 2863 dated 1983 (Republic of Turkey, 1983: article 10), the Ministry of Culture and Tourism is the principal public body responsible for the conservation of cultural heritage. Traditional buildings, historic monuments, archaeological sites and historic urban sites are under its remit. Other institutions are supporting its work. As the local public administrations, the municipalities are responsible for preparing or procuring conservation development and management plans and implementing them. They are also responsible for the appropriate preservation of historic streets and buildings. They are provided financial support for these conservation activities (Republic of Turkey, 2021a: article 10). The General Directorate of Foundations is responsible of conservation work regarding Seljuk and Ottoman period public buildings (Republic of Turkey, 2021b). The Higher Council for
Conservation of Cultural Property, under the authority of the Ministry's authority, is responsible for formulating conservation principles regarding preservation and conservation issues in the whole country (Republic of Turkey, 2021c). The regional commissions on the conservation of cultural property are the local branches of the Ministry. They make decisions on the listing of local cultural heritage and the appropriateness of local projects, plans and implementations regarding cultural heritage. The municipalities and regional directorates of foundations are represented in these regional commissions in accordance with the content of the discussion (Republic of Turkey, 2021d).

The act numbered 2863 is still in use with the amendments made in 1987 and 2004. These amendments have strengthened the institutions in charge of cultural heritage both administratively and financially (Gök, 2017:p.39; Güçhan and Kurul, 2009:p.39; Madran and Özgönül, 2005:p.105). As a result, the number of conservation 
implementations has increased. However, to what extend this increase in the number of conservation implementations is reflected in the quality of work is debatable. Some studies deal with the quality of current conservation implementations concerning the conservation of cultural heritage acts, plans and decisions in Turkey. Yildırım (2011:p.213) discusses the problems of urban conservation implementations by emphasizing the importance of appropriate management of actors and organizations. After examining three historic settlements, she concludes that success in urban conservation is achieved, when administrative actors, users, experts and sponsors are all active in the process. Teker (2013) questions the preservation of authenticity and integrity in building and site scale conservation implementations. He focuses on the historic urban centre of Gaziantep and evaluates the related decisions of the Regional Commission on the Conservation of Cultural Property. He concludes that while the integrity of the cultural heritage is partially conserved, authenticity is almost totally lost. This study focuses on the historic centre of Kuşadası, Aydın. Kuşadası is a middle-sized historic town under the pressure of mass tourism (Y1ldırım, 2011:p.212). The quality of conservation implementations in Kuşadası is questioned. The aim is to evaluate the impact of conservation planning and implementations on the cultural heritage values in this historic urban site of Kuşadası, Aydın, Turkey. The methodology includes integration of the qualitative research methods of the discipline of architectural restoration with quantitative methods of environmental impact analysis.

The research questions are listed below.

- To what extent have the conservation plan and the decisions of the Aydin Regional Commission on the Conservation of Cultural Property been effective in the improving and controlling construction activities in the cultural landscape of Kuşadası?

- To what extent have conservation values been sustained in Kuşadası?

The study's limit is the Kuşadası cultural landscape; the historic urban site is chosen as the study area. Listed buildings in the studied site were considered with their exterior characteristics. Their interiors were not surveyed. The restoration projects could not be obtained from the Regional Commission in Aydın or Kuşadası Municipality. So, measured surveys, restitution and restoration projects regarding the studied heritage were not evaluated. Similarly, there was difficulty in obtaining the decisions of the Regional Commission. So, the study was limited with the decisions published on the Internet: decisions taken between 2013 and 2016. Considering the fact that the Kuşadası historic urban site was listed in 1978 and the conservation development plan was ratified in 1994, the decision for the 1978-2013 period were requested from the Regional Commission, but they were not provided. In addition, in some cases, evaluating of the whole block of the discussed heritage could be more beneficial. However, in this study, only the buffer zone of each cultural heritage, including the lots next to the studied cultural heritage or opposite the street, were surveyed and evaluated.

\section{Material and method}

In the preliminary phase, conventional techniques were used to understand the case study site (literature research, archive research, site survey comprehending base map correction and photographic documentations; visual analysis, historical research and comparative study). The conservation plan was evaluated together with the latest base map of the local administration, which documents the urban layout in 2013, and a base map specifically for this study was produced. The decisions of the Regional Commission were classified regarding their content as listing, permission, cadastral operation and intervention.

Listing decisions included the listing of architectural heritage and identification of listing grades. Permission decisions included positive or negative opinions of the Regional Commission on issues such as determination of constructional limits, occupancy permits or change of function or leasing requests. Cadastral operation decisions included decisions related with ownership arrangements such as unification, subdivision, abandonment for road construction and development status. The intervention decisions included the requested or realised implementations, which varied as follows. Maintenance is the partial renewal of plaster and paint, roof tiles (Republic of Turkey, 1999: article I.1). Simple repair is a total renewal of plaster and paint, tiles, and change of ruined joinery (Republic of Turkey, 1999: article I.2.a). Renewal is rebuilding of the ruined building elements such as a wall, floor, etc. and addition of contemporary acclimatisation elements (Republic of Turkey, 1985: articles 21, 23; Republic of Turkey, 1999: article I.2.a). Mass addition is building a new service building on the site of the cultural heritage (Republic of Turkey, 1999: article II.c). Restoration is the comprehensive repair following restoration project (Republic of Turkey, 1999: article I.2.b). Reconstruction 
is total rebuilding based on a project (Republic of Turkey, 1999: article I.3). Demolition is controlled demolition of an extensively ruined cultural heritage (Republic of Turkey, 1999: article II.b). New building construction is constructing a new building in the buffer zone of a cultural heritage (Republic of Turkey, 1999: article I.3). Rehabilitation is improvement carried out at the urban space, e.g. organisation of street facades and urban open spaces, improvement of related infrastructure (Republic of Turkey, 2005: article 4). A site survey for documenting the qualities to be preserved and conservation problems of each cultural property and its buffer zone was made, and partial base map revisions were realised.

Finally, the evaluation process was designed considering the concepts of conservation as defined in the related international documents:

Washington Charter (ICOMOS, 1987) defines the qualities to be preserved in historic urban areas as lots and streets, relations between buildings and open spaces, the formal appearance of buildings, the relationship between the urban area and its setting, and the functions the site has acquired over time.

Nara document (ICOMOS, 1994) points out that authenticity is the qualifying factor concerning cultural heritage values. These values may be understood as long as the related sources of information are accurate. The sources include spirit of a place, location and setting, design, use, traditions, material and techniques.

The Quebec Declaration (ICOMOS, 2008) emphasises that the traditional cultural groups safeguard the spirit of their place the best (ICOMOS, 2008: article 9).

Valetta Principles (ICOMOS, 2011) underlines that the identity of a place is closely related to the preservation of its cultural traditions, traditional techniques, and spirit (ICOMOS, 2011: article 4.a.e).

Burra Charter (ICOMOS, 2013) states that conservation of a place requires a correct understanding of its cultural significance. If its use, visual setting, related objects, and spiritual relationships are of cultural significance, they must be sustained.

Delhi Declaration (ICOMOS, 2017) underlines the importance of conservation of living heritage in a place together with the physical evidence, e.g. transfer of knowledge and skills, traditions and life styles.

UNESCO Operational Guidelines also states that cultural heritage values may be well understood if the related information sources are credible and accurate. In addition, the importance of the wholeness of a cultural asset is underlined. This means that all elements expressing its value are preserved, the heritage is of adequate size, and negative effects of change are not present (UNESCO, 2019: articles 80, 81, 82, 88).

In order to understand the effect of conservation planning and implementations on the heritage values of the Kuşadası historic urban site, first, the qualities to be preserved are defined: buildings, lots, streets, and location and setting. Secondly, the criteria concerning the preservation of values of each quality are defined. The criteria for a building are the faithfulness of its function, design; and construction technique and material (Table 1, Yönetken, 2018). The criteria for a lot are the wholeness of the relationship between the lot and the related building, and the visual setting (Table 2, Yönetken, 2018). The criteria for a street are the truthfulness of its circulation function, plan layout and silhouette, construction technique and material of the facades and ground, and spirit of place (Table 3, Yönetken, 2018). The criteria for the location and setting are the wholeness of the visual setting and the spiritual relationships (Table 4, Yönetken, 2018). Thirdly, a grading system is proposed by adapting the techniques applied in environmental impact analysis (Ijas et al., 2010: p.85; Pastakia and Jensen, 1998:p.470; Sarupria et al., 2019). It is considered that converting qualitative data into a quantitative form may help compare results for different cultural heritage.

Table 1 Criteria for grading buildings (Yönetken, 2018)

\begin{tabular}{|c|c|c|c|c|}
\hline \multirow{2}{*}{ Criteria } & \multicolumn{4}{|c|}{ Grade } \\
\hline & -1 & 0 & 1 & 2 \\
\hline Function & inappropriate function & abandoned building & refunctioned building & $\begin{array}{c}\text { original function is } \\
\text { continuing/ presented as a } \\
\text { cultural asset }\end{array}$ \\
\hline Exterior Design & $\begin{array}{c}\text { all qualities totally altered } \\
\text { (form, scale, technique, } \\
\text { material) }\end{array}$ & $\begin{array}{l}\text { original form, scale partially } \\
\text { sustained color and texture } \\
\text { totally altered }\end{array}$ & $\begin{array}{c}\text { original form, scale, } \\
\text { color and texturepartially } \\
\text { sustained }\end{array}$ & $\begin{array}{l}\text { original form, scale, color } \\
\text { and texture sustained }\end{array}$ \\
\hline $\begin{array}{l}\text { Material \& Const. } \\
\text { Tech. }\end{array}$ & $\begin{array}{l}\text { renewed with a different } \\
\text { const. technique, material }\end{array}$ & $\begin{array}{l}\text { original const. tech. } \\
\text { partially sustained material } \\
\text { extensively renewed }\end{array}$ & $\begin{array}{l}\text { original const. tech. } \\
\text { sustained but material } \\
\text { partially renewed }\end{array}$ & $\begin{array}{l}\text { original const. tech. and } \\
\text { material totally sustained }\end{array}$ \\
\hline
\end{tabular}


Table 2 Criteria for grading lots (Yönetken, 2018)

\begin{tabular}{|c|c|c|c|}
\hline \multirow{2}{*}{ Criteria } & \multicolumn{3}{|c|}{ Grade } \\
\hline & -1 & 1 & 2 \\
\hline $\begin{array}{l}\text { Building and } \\
\text { lot relationship }\end{array}$ & original building demolished & $\begin{array}{l}\text { half of building sustained and/or } \\
\text { extensive mass additions in the lot }\end{array}$ & $\begin{array}{l}\text { building and the other elements in the lot } \\
\text { sustained }\end{array}$ \\
\hline Visual setting & $\begin{array}{l}\text { total loss of elements of the physical } \\
\text { context in the close-by env./ inappr. } \\
\text { restorations, inharmonious new } \\
\text { buildings and lack of maintenance in the } \\
\text { neighborhood }\end{array}$ & $\begin{array}{l}\text { physical context is partially sustained } \\
\text { in the close-by environment (buffer } \\
\text { zone), lack of maintenance caused by } \\
\text { abandonment or budget restrictions }\end{array}$ & $\begin{array}{l}\text { original physical context in the close-by } \\
\text { environment totally sustained, qualified } \\
\text { urban interventions }\end{array}$ \\
\hline
\end{tabular}

Table 3 Criteria for grading streets (Yönetken, 2018)

\begin{tabular}{|c|c|c|c|}
\hline \multirow{2}{*}{ Criteria } & \multicolumn{3}{|c|}{ Grade } \\
\hline & -1 & 1 & 2 \\
\hline $\begin{array}{l}\text { Visual } \\
\text { setting }\end{array}$ & $\begin{array}{l}\text { total loss of traditional street pattern, } \\
\text { solid-void organisation, inapp. restorations, } \\
\text { inharmonious new buildings and lack of } \\
\text { maintenance in the neigborhood }\end{array}$ & $\begin{array}{l}\text { original physical context partially } \\
\text { sustained: some alterations in traditional } \\
\text { solid-void pattern and street hierarchy }\end{array}$ & $\begin{array}{l}\text { original solid-void pattern andtraditional } \\
\text { hierarchy of streets in its close-by } \\
\text { environment totally sustained }\end{array}$ \\
\hline $\begin{array}{l}\text { Spiritual } \\
\text { relationships }\end{array}$ & total loss of the locals in the neighborhood & $\begin{array}{l}\text { partial continuation of the neighborhood } \\
\text { culture }\end{array}$ & $\begin{array}{c}\text { continuation of the neighborhood culture } \\
\text { (e.g. traditional houses continuing to be } \\
\text { used by the local families) }\end{array}$ \\
\hline
\end{tabular}

Table 4 Criteria for grading location and setting (Yönetken, 2018)

\begin{tabular}{|c|c|c|c|c|}
\hline \multirow{2}{*}{ Criteria } & \multicolumn{4}{|c|}{ Grade } \\
\hline & -1 & 0 & 1 & 2 \\
\hline Function & total loss of circulation quality & $\begin{array}{c}\text { presence of obstacles against } \\
\text { circulation (illegal parking } \\
\text { etc.) }\end{array}$ & $\begin{array}{l}\text { extension of commercial } \\
\text { functions in the shops to } \\
\text { street, limiting pedestrian } \\
\text { circulation }\end{array}$ & $\begin{array}{l}\text { continuation of circulation } \\
\text { function }\end{array}$ \\
\hline $\begin{array}{l}\text { Street plan } \\
\text { and silhouette }\end{array}$ & all qualities changed & $\begin{array}{c}\text { change in the traditional sense } \\
\text { of enclosure }\end{array}$ & $\begin{array}{c}\text { original plan layout and } \\
\text { silhouette sustained, alteration } \\
\text { in color and texture }\end{array}$ & $\begin{array}{c}\text { original plan layout, facade } \\
\text { organisations, scale, color and } \\
\text { texture sustained }\end{array}$ \\
\hline $\begin{array}{l}\text { Material \& } \\
\text { Const. Tech. }\end{array}$ & $\begin{array}{l}\text { material totally renewed/ } \\
\text { renewed with a different } \\
\text { const. tech. }\end{array}$ & $\begin{array}{l}\text { original const. tech. partially } \\
\text { sustained material extensively } \\
\text { renewed }\end{array}$ & $\begin{array}{l}\text { original const. tech. sustained } \\
\text { but materialpartially renewed }\end{array}$ & $\begin{array}{l}\text { original const. tech. and } \\
\text { material totally sustained }\end{array}$ \\
\hline Spirit of Place & $\begin{array}{l}\text { only touristic activities } \\
\text { realised on the street }\end{array}$ & $\begin{array}{l}\text { generally touristic activities } \\
\text { realised on the street, limited } \\
\text { representation of traditional } \\
\text { lifestyle }\end{array}$ & $\begin{array}{l}\text { continuation of traditional } \\
\text { life, a few touristic facilities } \\
\text { extending to the street }\end{array}$ & $\begin{array}{c}\text { continuation of traditional life } \\
\text { (e.g. local women chatting } \\
\text { in their gateways, children } \\
\text { playing street, etc.) }\end{array}$ \\
\hline
\end{tabular}

\section{Historical, legal and administrative background}

In chorological order, the studied region was dominated from $3000 \mathrm{BC}$ to $1100 \mathrm{BC}$ by Hittites, Carians, Lelegs and Ionians. Persians captured it in 546 BC, Macedonians in $333 \mathrm{BC}$ and the Roman Empire in 133 BC (Sağdıç, 1988:p.19). The ancient harbour of Ephesus was filled in as a result of natural formation (Kiel, 2000:p.405). In Medieval sources, Scala Nova was mentioned as the region' port (Kiel, 2000:p.413). Another port, a castle, and a caravanserai were built on the site in the early $17^{\text {th }}$ century due to the economic developments at the end of the $16^{\text {th }}$ century (Faroqhi, 1993:p.145). From this time onwards, Kuşadası began to develop. The settlement included flat zones close to the coast and inclined zones on the hill skirt. Camikebir neighbourhood, which was established in the citadel, was settled on flat land to at the northeast. It had narrow streets, which were almost perpendicular to each other. Dağ neighbourhood was at the southwest of Camikebir neigborhood and settled on the hillside. As a result of the steep slope, streets with stairs and a sea vista were common here. The streets parallel to the slope had an organic plan. Hacifeyzullah, Cami-i Atik and Alacamescit neighbourhoods to the south were on almost flat land. The introverted family life continued behind the high courtyard walls and openings protected with shutters and lattices. The greenery in the courtyards enriched the housing units and provided shade to the neighbouring streets where local women and children gathered. Those living on the hillside could follow the heads of their families sailing in the bay. Hawkers passed by. Artisans worked in their gateways in the commercial zones, and hawkers sold their wares. 
The construction of the İzmir-Aydın railway in the 1860s rapidly increased the regions's development (Atilla, 2002:p.301). In the late $19^{\text {th }}$ century (Fig. 1, Map Stack), new Greek villages were established, in parallel with the western policy supporting their movement from the Aegean islands to the mainland (Pekak and Aydın, 1998:p.126). The dual ethnic structure composed of Turkish and Greek nationals continued until the 1922 population exchange. In the second half of the $20^{\text {th }}$ century, Kuşadası has underwent rapid transformation as a result of tourism.

In 1976, the Neopolis (west of Kuşadası) cultural landscape was ratified as an archaeological site. Two houses and six monuments at the centre were listed (Regional Commission, 1976a). In 1978, the historic urban site of Kuşadası was listed (Fig. 2, Apple Maps). The historic urban site concept had just entered the Turkish legal framework in 1973 with the act numbered 1710 (Üstünkök, 1989:p.117). The conservation principle of the Higher Council numbered 61 was ratified in 1984. This decision has been criticised for its reconstructive scope. For example, mass and facades of group IIA2 buildings were to be preserved, because they were considered valuable with their contribution to the historic townscape. Their structural system and spatial order, however, could be renewed. In 1986, the revision of the historic urban boundaries of Kuşadası and a re-definition of the listing grades of the architectural heritage were realised following the principal decision 61 (Regional Commission, 1986). Thus, the basic concepts of conservation, authenticity and integrity, were threatened.

At the same time, the Regional Commissions on the Conservation of Cultural Property were established and held responsible basically for listing and grading of cultural property, and evaluating conservation plans and restoration projects according to the 1983 act (Republic of

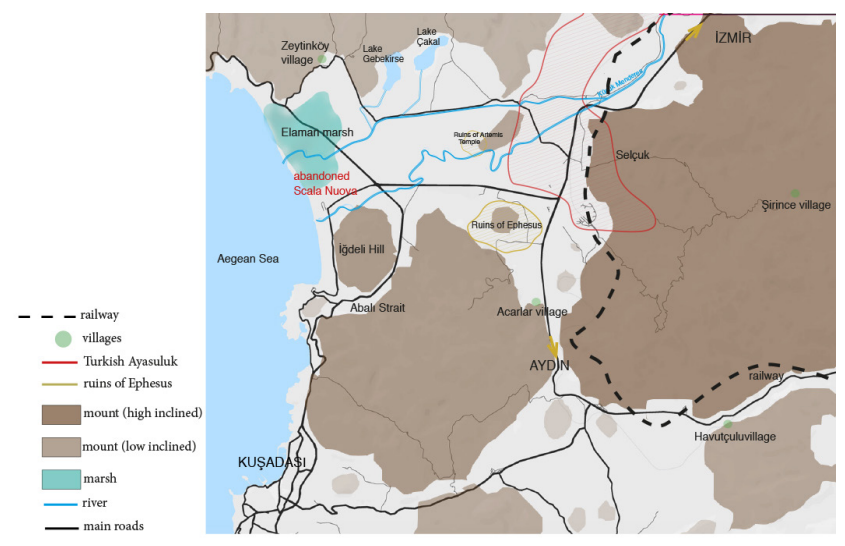

Fig. 1 Kuşadası cultural landscape in the late $19^{\text {th }}$ century (revised from Map Stack)

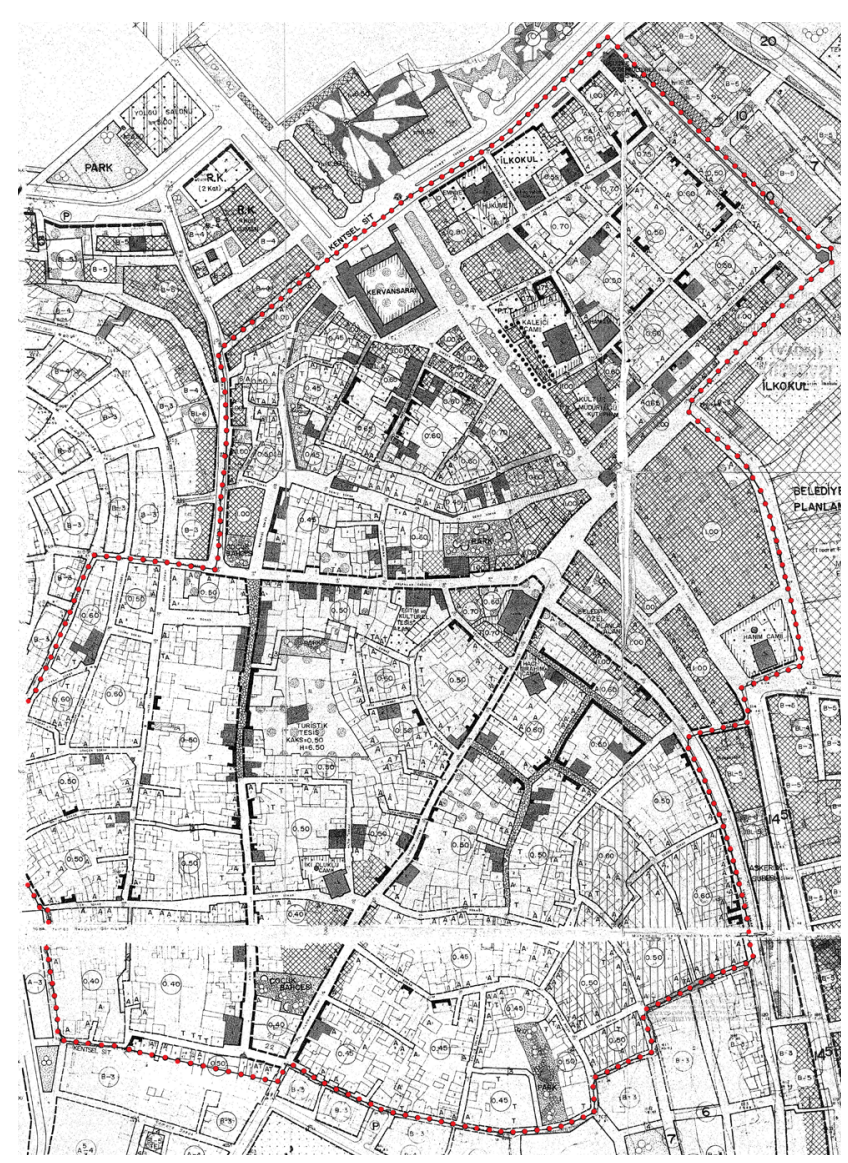

Fig. 2 The position of Kuşadası historic urban site (revised from Apple Maps)

Turkey, 1983). The first conservation development plan for the Kuşadası historic urban site was ratified in 1994 (Fig. 3, Kutluay, 1994) by the Regional Commission (İzmir Number II Regional Commission on the Conservation of Cultural and Natural Property). This plan (Kutluay, 1994) focused on the rehabilitation of vernacular buildings. It proposed the preservation of a large number of facades of traditional buildings and their courtyard walls, while no protection was considered for the buildings themselves. In the plan, the term "facades to be preserved" was defined as the rehabilitation of the façade of a historical building through preservation of its proportions, form and dimensions, and simple repair of its elements. This definition was adopted by the related regional commission and has been used in its decisions, although the principles for grouping listed buildings have been revised a several times since then: 1987 (Regional Commission, 1987), 1994 (Kutluay, 1994), 1999 (Regional Commission, 1999).

Consequently, the Conservation of Cultural Heritage Act of 1983 was revised in 2004 (Republic of Turkey, 1983). As a result, the concept of a management plan has been introduced to the Turkish legal framework. However, 


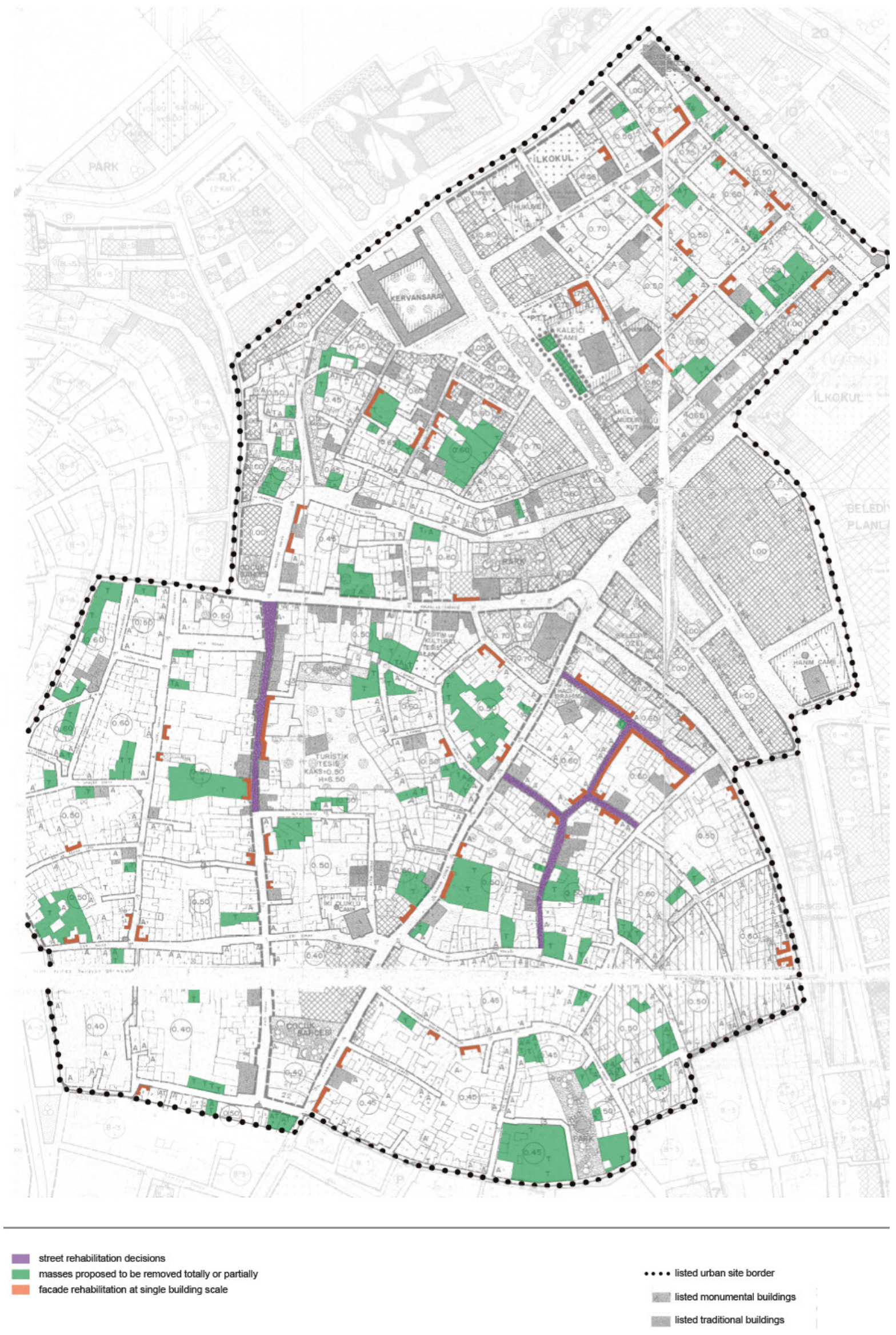

Fig. 3 Interventions proposed in the Conservation Development Plan (revised from Kutluay, 1994) 
a management plan for the Kuşadası historic urban site has not been prepared to date. Similarly, the conservation plan has not been updated, although the listing decisions regarding the heritage in Kuşadası cultural landscape were revised (1986, 1987, 2013) (Fig. 4, Kutluay, 1994). Nevertheless, the act dated 2004 has encouraged the conservation of cultural heritage in Turkey since new resources were allocated. Conservation, Implementation and Supervision Offices were established within municipalities. Simplification of bureaucratic procedures was undertaken (Madran and Özgönül, 2005:p.105). Thus, the 2000s have been fruitful in terms of conservation activities in Kuşadası (Yıldırım, 2011:p.212). In coordination with the local universities, the local administration realised several projects, including street rehabilitation and building restoration (Fig. 5, Kutluay, 1994). Although the conservation plan gave priority to the residential site representing the traditional way of life, the local administration chose to make implementations in the historic commercial zone, which is at the same time the touristic area. These conservation activities lost their impetus in the 2010s.

The decisions of the Regional Commission taken between 2013 and 2016 are mainly related to interventions at single building scale (126 of 149; 85\%). Thus, remaining $15 \%$ of the decisions are related to urban scale interventions (Fig. 6, Yönetken, 2018).

Of the decisions $40 \%$ (59 of 149) are related to the listed cultural heritage. Some $9 \%$ of the decisions (14 of 149) are related to the facades to be conserved; $41 \%$ of the decisions (61 of 149) are related to new/unlisted buildings that are located in the buffer zones of the listed cultural heritage (Fig. 7, Yönetken, 2018). Of the decisions are related to streets, $10 \%$ are to be preserved in the cultural landscape of Kuşadası.

\section{Characteristics of the cultural heritage}

The historic urban site of Kuşadası (Fig. 8, Google Maps) includes five neighbourhoods (Bektaş, 1993:p.156) composed of historic monuments, traditional houses and shops (Fig. 9, Arslan, 1970s), and human-scaled streets. Among the monuments studied, there are three fountains; Ev Tekkesi listed in 1994 (Regional Commision, 1994), Çeşmebaşı listed in 1978 (Regional Commision, 1978), Eminekadın dated 1807-1808, listed in 1978 (Regional Commision, 1978); Öküz Mehmet Paşa caravanserai dated 1618, listed in 1976 (Regional Commision, 1976b); a section of the fortification walls and the citadel gate dated to the first half of the $17^{\text {th }}$ century and listed in 1978
(Regional Commision, 1978); two mosques; Kaleiçi dated 1618, listed in 1976 (Regional Commision, 1976b) and Hacı İbrahim Ağa dated 1687, listed in 1978 (Regional Commision, 1978); and the government house representing Ottoman modernisation and listed in 1978 (Regional Commision, 1978).

The fountains enrich the streetscape and document the period when there was no running water in the houses. Only one of them continues its function: Ev Tekkesi. Two have been extensively intervened (Ev Tekkesi, Eminekadın). The Çeşmebaşı Fountain still reveals its authentic characteristics: rubble stone masonry structure with a central spout trace, two side niches and a basin, all crowned with an arch. It is in ruins: the top portion and the spout are missing, while the original ground level has been elevated in its vicinity.

The caravanserai represents the historical period in which Kuşadası was a base for coastal protection. The original structure had partially collapsed because of an earthquake before 1922. After its reintegration in 1964 by the General Directorate of Foundations, it had been used as a hotel. Rows of bricks in the stone masonry walls help to distinguish between the authentic and additional sections. The traditional shops flanking it (Çobanoğlu, 2007:p.26) and many of the traditional houses in the vicinity, which were preserved until the 1960s, are no longer present. There are multi-story structures and/or large masses in its vicinity, although their removal was proposed in the conservation development plan. Today, the caravanserai is used for socio-cultural purposes: e.g. gathering of women on Women's Day.

A section of the fortification walls (Fig. 10, Yönetken, 2018) have been preserved on Sağlık Street. The citadel gate is a square prism with an arched opening at the ground level. Both of the structures are rubble stone masonry. The pedestrian circulation continues throughout the gate. Its hipped roof, arched windows and balcony, and the stairs leading to the first floor are period additions. The first floor is to be re-functioned as a micro museum. The relation of the citadel gate and the fortification walls cannot be perceived because of the new shops flanking them. The traditional commercial pattern, which has developed in time, is also damaged as well. The inharmonious buildings in the vicinity have not been removed so far, although this was proposed in the conservation development plan.

The Kaleiçi Mosque (Fig. 11, Arslan, 1960s; Yönetken, 2018) is a single domed mosque with a colonnaded portico. The building has generally maintained its authenticity, 


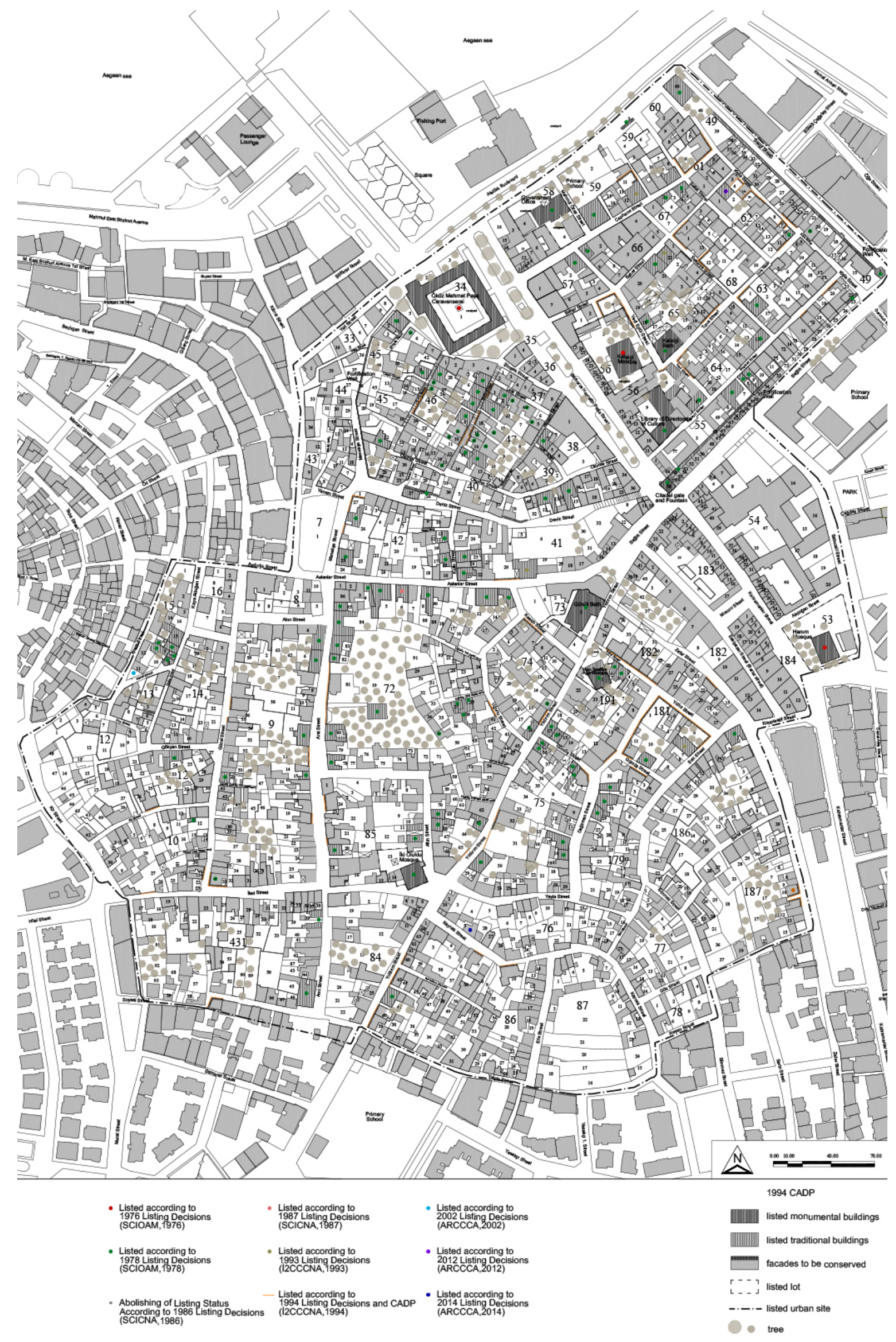

Fig. 4 Evolution of Listing Decisions (revised from Kutluay, 1994) 


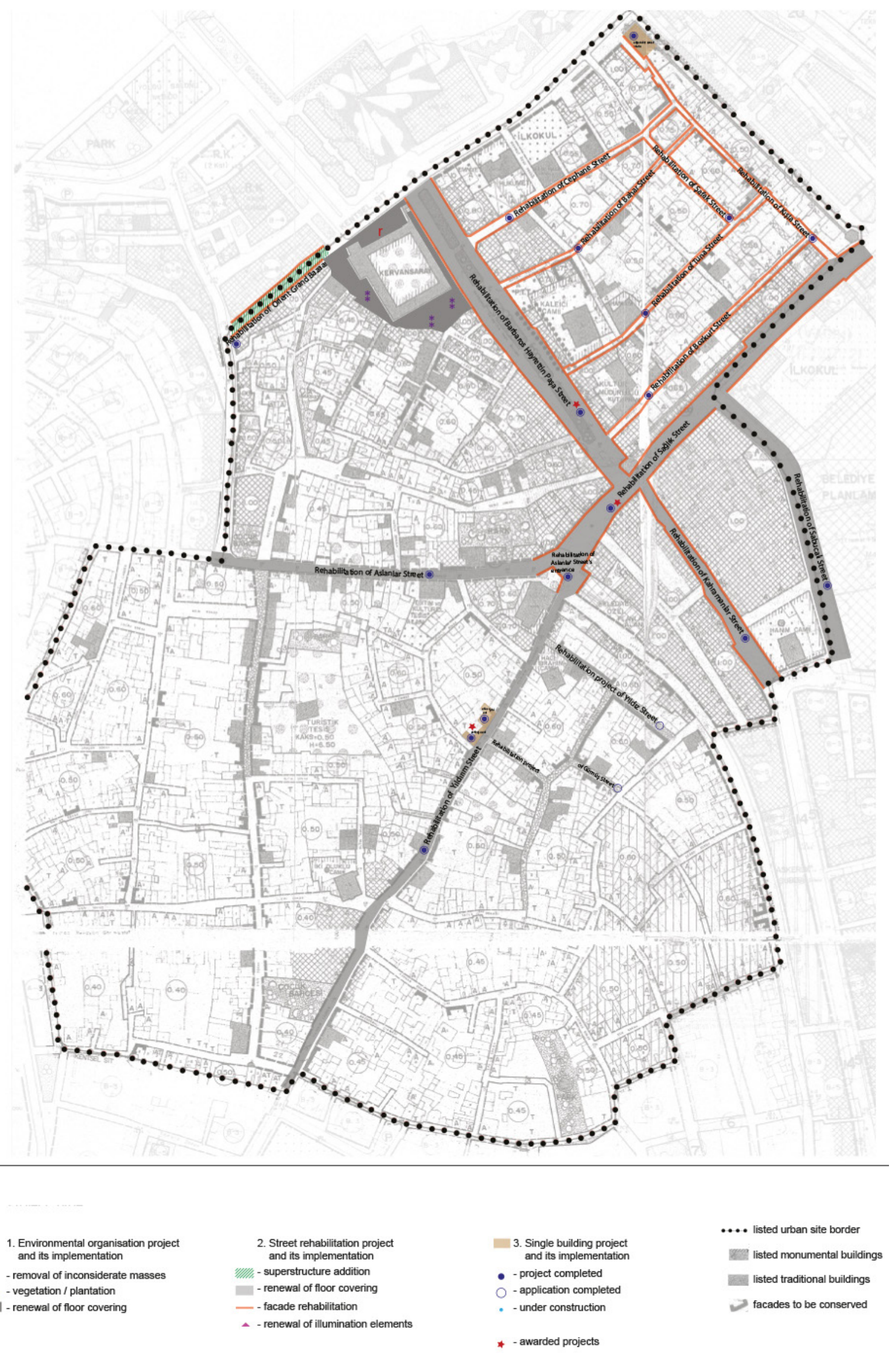

Fig. 5 Urban conservation implementations and building restorations of Kuşadası Municipality in 2000s (revised from Kutluay, 1994) 


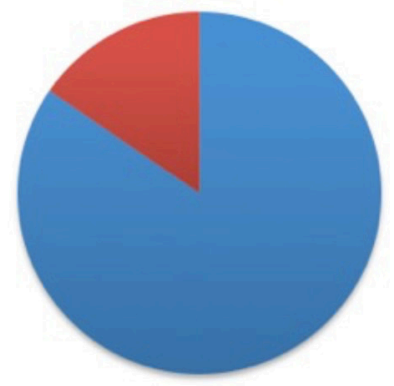

wingle building scale

= urban scale

Fig. 6 Distribution of decisions according to scale (Yönetken, 2018)

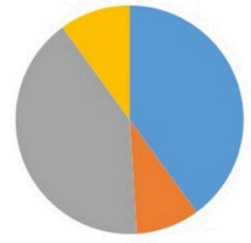

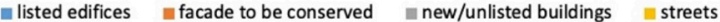

Fig. 7 Distribution of decisions according to the type of property (Yönetken, 2018)

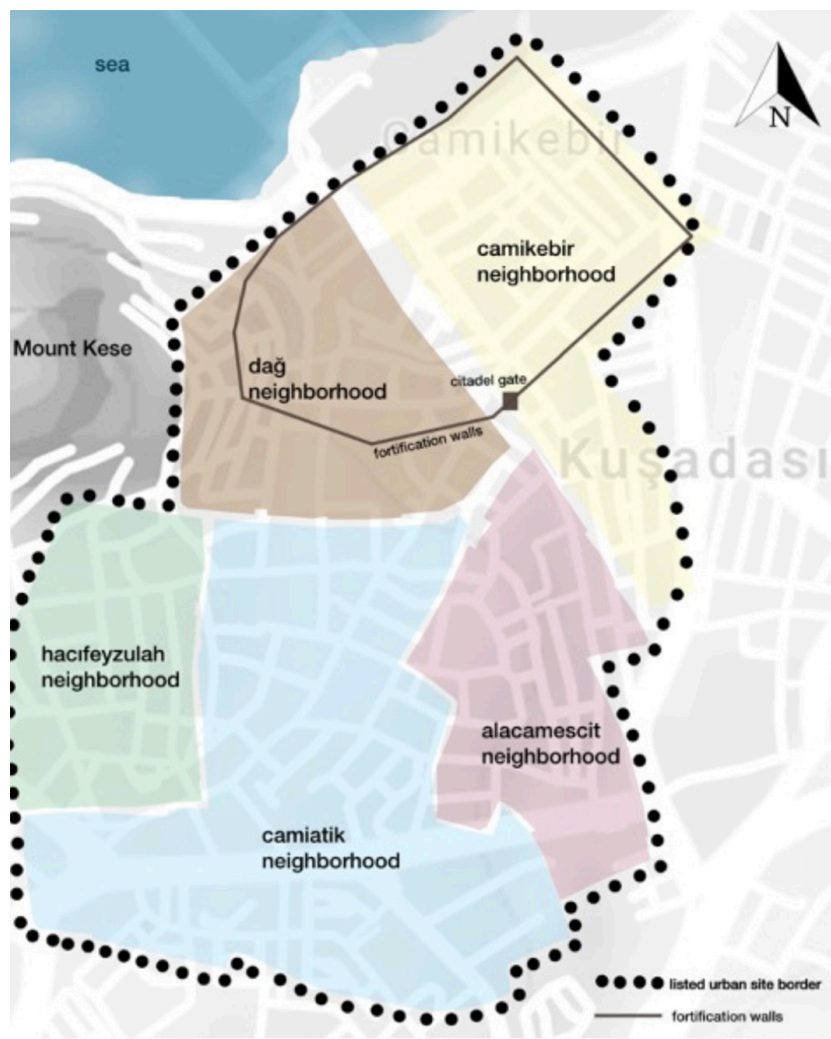

Fig. 8 Neighborhoods in the historic urban site (revised from Google Maps)

but the lot is full of mass additions: a masjid, toilets and an ablution space. They are all approved by the Regional Commission. Preservation of the modest scale shops flanking the lot of the mosque at its west has not been proposed in the conservation development plan, but they should be evaluated as part of the historic urban site. There are

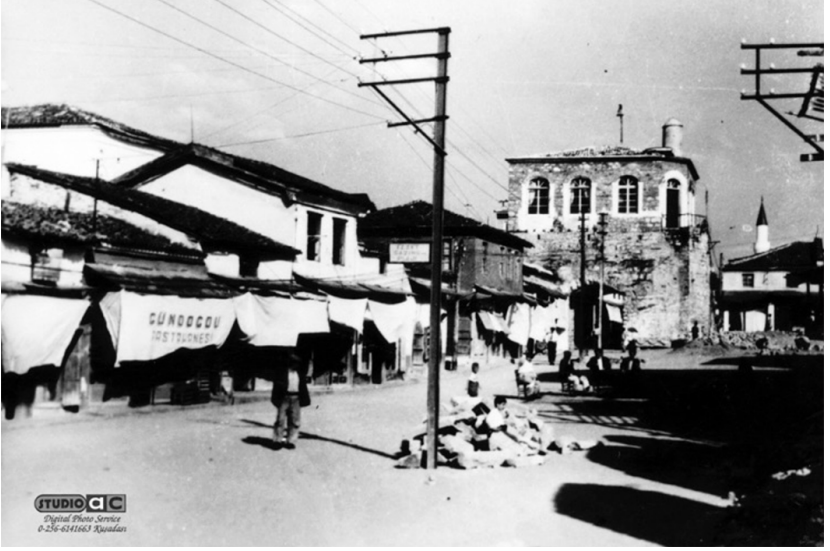

Fig. 9 Shops on Kahramanlar Street (Arslan, 1970s)

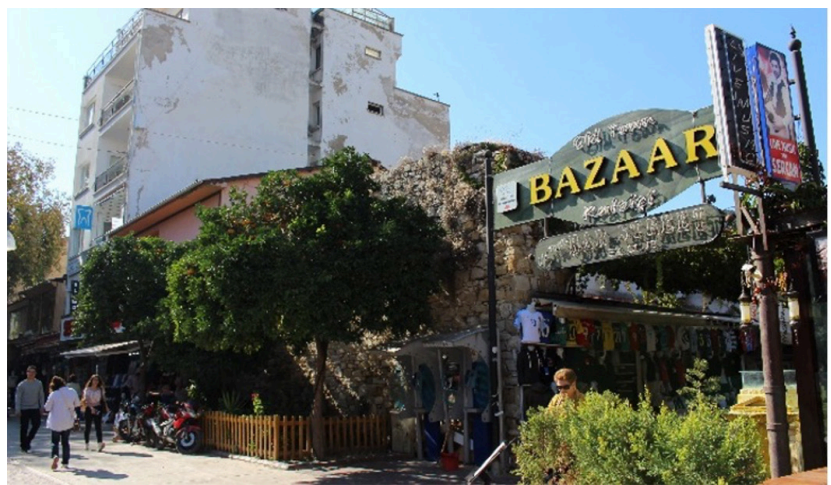

Fig. 10 Fortification wall as viewed from Sağlık Street (Yönetken, 2018)

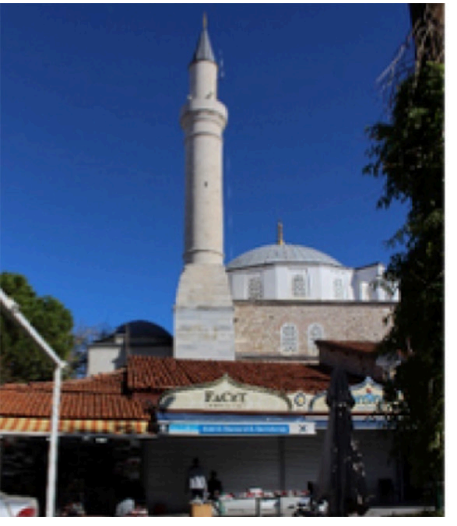

(a)

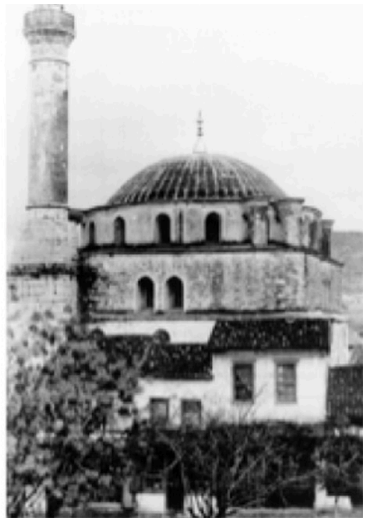

(b)
Fig. 11 Kaleiçi Mosque as viewed from west (a) in 2018 (Yönetken, 2018), (b) in the 1960s (Arslan, 1960s)

buildings with large lot coverage ratios and heights to the north and south. They were evaluated as inharmonious in the conservation targeted development plan, but their removal was not been realised.

The Hacı İbrahim Ağa Mosque comprises a cubical praying space with a hipped roof and a collonaded portico. The mass has preserved its authentic characteristics in general, but the lot size has been diminished with the neighboring buildings constructed on the monument's 
open spaces. Those at the east are traditional structures, which are in ruins today. They seem to be constructed over the original graveyard. The mosque has been restored recently, but the restoration project, approved in 2015, has proposed no measures for the ruins to the east. The ablution space added to the courtyard has further increased the density. The inharmonious new buildings in the vicinity whose removal was proposed in the 1994 plan still exist. Lot 23, flanking the mosque site to the south, is one of these inharmonious structures. The regional commission has approved its rehabilitation in 2015. This is a contradiction between the plan and the commission decisions.

The government house continues its function. It is a prismatic structure. The original Neoclassical characteristics of the central mass were partially replaced with early Republican ones. The primary preservation problem is the number of additional masses in the courtyard. They are neither present in the plan nor define an organized open space in the way they are put together. Inharmonious buildings in the vicinity have not been removed, although this was proposed in the 1994 plan.

Moreover, urban density has further increased with mass additions. For example, the high lot coverage ratio of the neighboring primary school also contradicts with the plan as well. Unfortunately, the level of mass additions is more in the public structures.

The traditional housing units represent the late Ottoman period. Most of them were listed in 1978 (Regional Commission, 1978). They are extroverted. The main masses juxtapose the streets. The ground floors are masonry, while the first floors are timber frames finished with wood lath and plastering. Hipped roofs with over and under tiles, projections, curvilinear profiles, bird motives, casings, shutters, lattices and whitewash are common characteristics of the facades. Rear courtyards are common. Side courtyards are sometimes seen. In the inclined zones, courtyards are composed of a series of terraces. The studied houses are fifteen in number $(9 / 49,46 / 7$, 49/40, 56/9, 62/2, 65/18, 65/22, 67/2, 72/12, 75/30, 86/41, $181 / 6,181 / 10,186 / 1,191 / 17$ in the order of block/lot). Many of them have been abandoned (4 of 15: 9/49, 65/18, $181 / 10,186 / 1)$. Some have been converted into a touristic restaurant ( 1 of $15 ; 62 / 2$ ), a shop ( 1 of $15 ; 65 / 22$ ), a ceramic workshop ( 1 of $15 ; 67 / 2$ ), a cultural center (1 of $15: 75 / 30)$; a youth center ( 1 of $15: 86 / 41)$, a hostel (181/6) or a coffee house (191/17). Some are in ruins (1 of 15; 9/49). Some are not well maintained ( 2 of 15: 72/12, 186/1). In the coastal zone, interventions are more radical: e.g. reconstruction of the central mass with the original rubble stones during restoration (1 of 15: 49/40) (Fig. 12, Regional Commission, 2008). Alteration of window and casing forms, renewal of the cumbas (projection), joineries and plaster; removal or renewal of iron shutters, the addition of iron railings and sheds, usage of bright colors on the facades are also common. In general, street-lot and lot-main mass relations have been preserved in the residential areas, but lot coverage ratios have increased with mass or shed additions. The inharmonious buildings whose removal was proposed in the plan have not been removed.

In addition to these listed housing units, the conservation plan defines facades to be preserved. The majority of these are also the street facades ( 6 of 7 and courtyard walls (1 of 7 ) of traditional houses as well. Seven facades have been studied. Many are in use as houses (47/16), restaurants (62/11), an architecture office (182/22), and a house of gastronomy (182/28). Some are abandoned and in ruins $(182 / 29,30,31,32,33 ; 191 / 12)$. Their alterations are similar to the listed traditional houses.

The traditional shops are generally in the Camikebir Neighborhood. They are single or double storied buildings flanking each other and directly entered from the street. Their scale, architectural elements, construction technique, and material are similar to the houses' previously described characteristics. In addition, canopies were provided for shade and rain protection. They were mostly listed in 1978.

The original sections of streets are narrow (between 2.10 and $3.80 \mathrm{~m}$ ) and surrounded by monuments, traditional buildings and their courtyard walls. Their original covering is totally lost: screed or asphalt is observed. In the level zones, a grid layout of streets exists (Kahramanlar, Kutlu, Hücum, Lale, Menekşe, Cesur, Mumcu). Those on the hill side either follow the contours and have an organic plan (Okurlar, Deniz), or are perpendicular to the slope, have stairs and vista of the bay (Çetin, Mutlu). Eleven

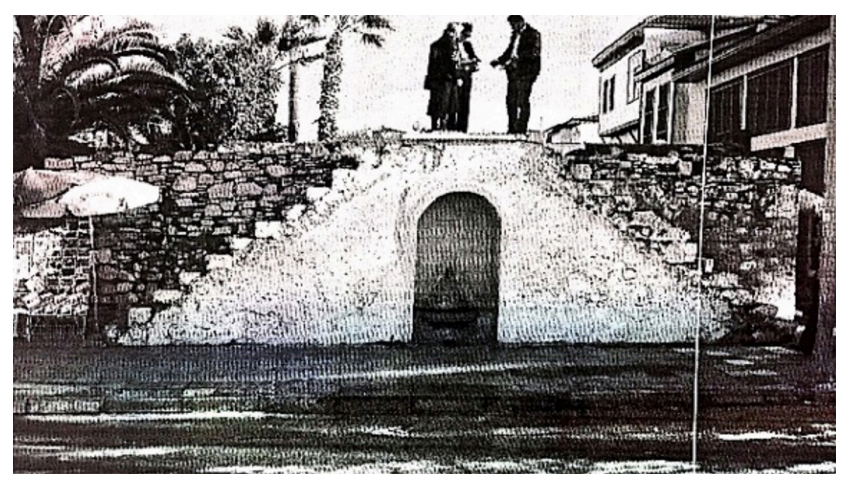

Fig. 12 The building in block 49, lot 40 as viewed from the north restoration phase (Regional Commission, 2008) 
streets have been studied. Along the streets, the silhouettes of traditional buildings and their courtyard walls are generally preserved, but there are also multistoried apartment buildings. Enlargement of openings, renewal of joinery, preference for bright colours for painting the facades, and addition of air conditioners and sign boards to the facades are typical alterations. Static elements randomly placed in front of the street facades and goods piled up by the building entrances have a negative impact on visual quality.

\section{Results}

The monuments are well maintained in general. Original functions of mosques and some fountains have been conserved, while the caravanserai and the citadel gate have been utilized with socio-cultural functions. In turn, the majority are publicly accessible. The authentic design characteristics of monumental structures are preserved in general, while the construction technique and material are often renewed with contemporary interventions (Fig. 13, Yönetken, 2018). Mass additions extensively alter building-lot relationships with the monuments. The original functions of traditional buildings are often lost. They are converted into touristic facilities. Their scale, mass and façade design is preserved in general, while the façade elements have been often altered.

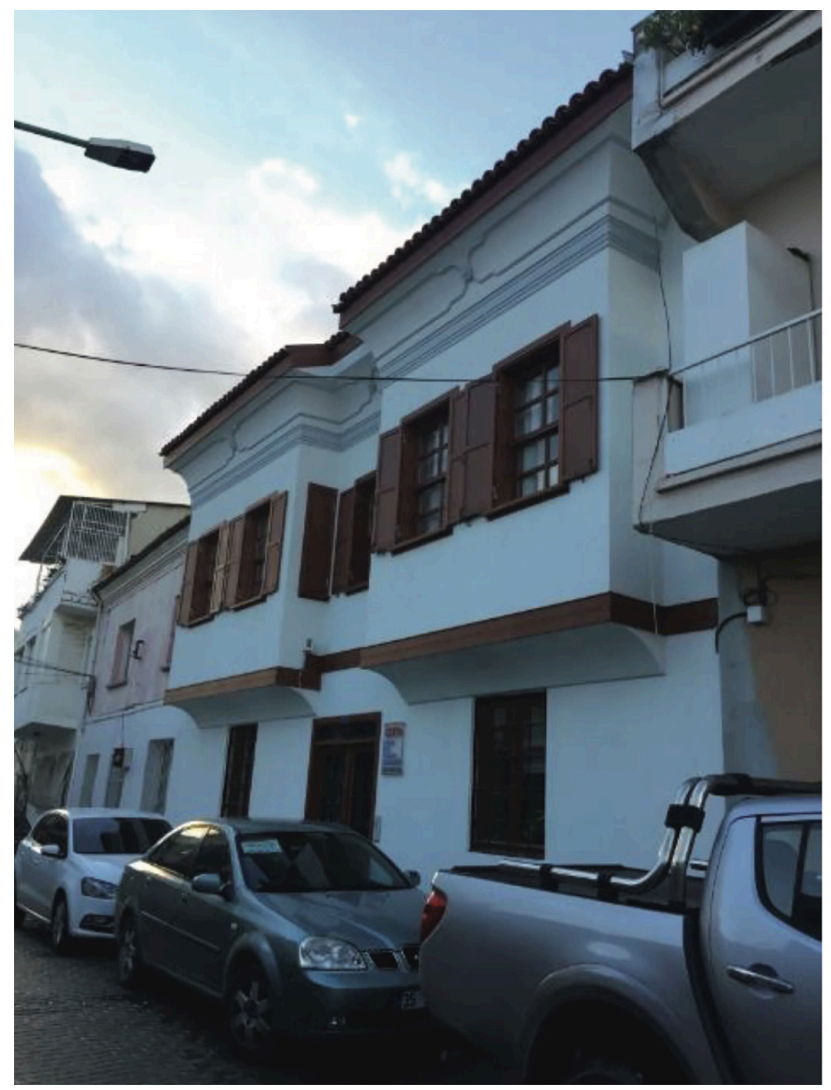

Fig. 13 The building in block 182, lot 22, photograph (Yönetken, 2018)
Similarly, the facades' colour and texture have been altered since the repair material is often different from the original. The alterations of the facades to be conserved are generally a result of their enlargement; for example, an increase in building height may be seen. The lot-building relationship of traditional buildings is relatively better preserved compared to the monuments. However, small service masses have been added to many of the courtyards as well. The visual setting of these heritage structures has been altered with urban renewal. The removal of inharmonious buildings, which was proposed in the conservation plan, has not been realized in general. In turn, the perception of monuments with documentary value is hindered, such as the fortification wall ruins (Fig. 14, Yönetken, 2018). The human scale of the traditional buildings is also negatively affected.

The streets serve as a scene for tourist recreation: e.g. tables, chairs, shopping counters, flower pots, sign boards, and the bright colors of surfaces, etc. are provided to

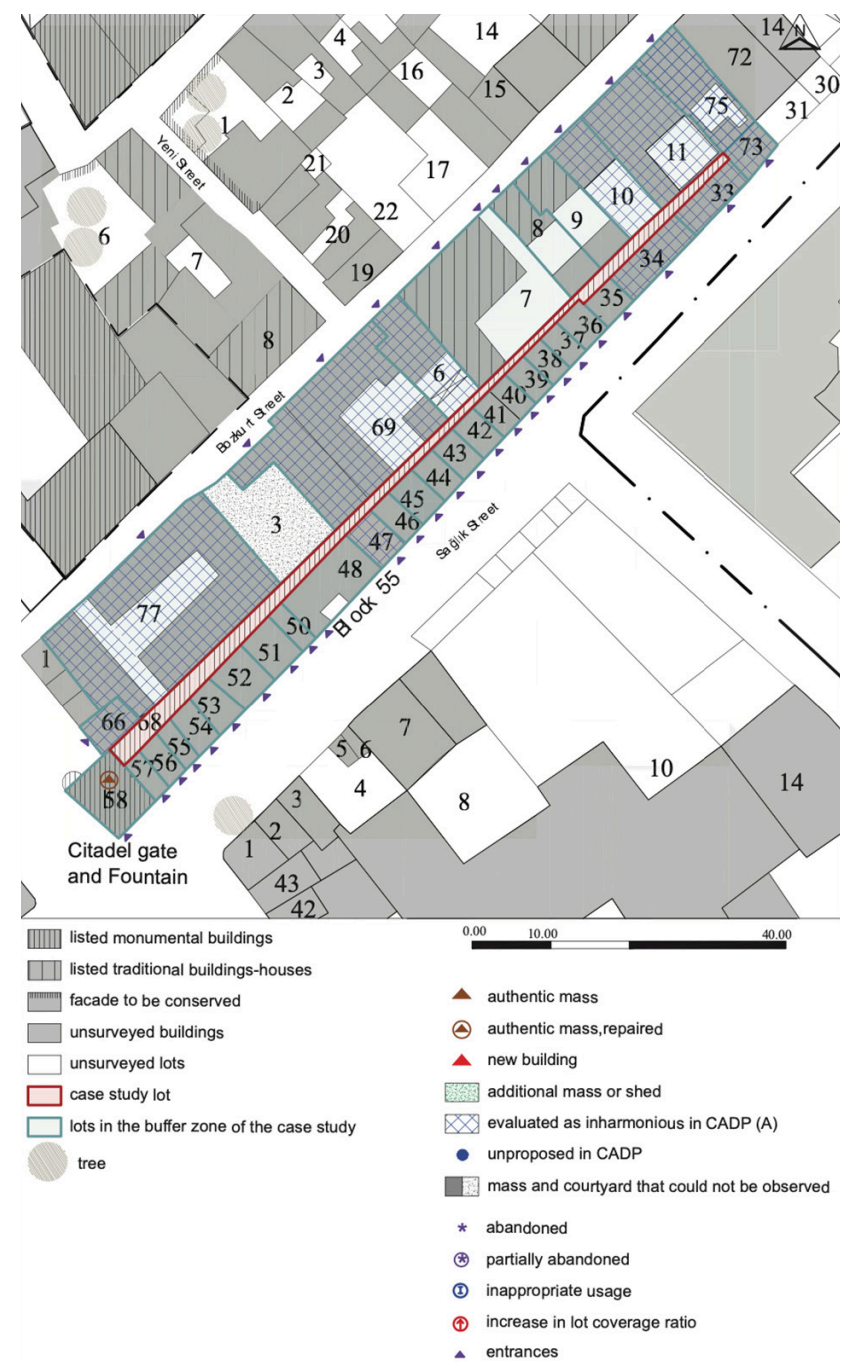

Fig. 14 Survey of the fortification wall remain, plan (Yönetken, 2018) 
appeal to them. Interactions of locals on these streets are seldom seen. Original plan layouts are often preserved, but the hierarchy of traditional streets in the neighborhoods has been altered with urban interventions made after the 1960s; e.g. newly opened short cuts, widening and similar. The silhouettes and sense of enclosure have been slightly altered with the contemporary structures. As a result, the location and setting have preserved its visual qualities with some renewals, but the neighborhood culture of the old Kuşadası is experienced in very limited areas.

The conservation plan has given priority to the rehabilitation of residential zones, but the Municipality has realised the majority of street rehabilitations at the commercial zones. The Conservation Commission has discussed the streets in the residential zones, but only on minor issues, e.g. appropriateness of the paint on their stairs (Fig. 15, Yönetken, 2018). The plan has proposed the removal of an important number of inharmonious buildings. These have also not been realized. Moreover, the Conservation Commission has taken decisions for the rehabilitation of some of these inharmonious buildings. The Commission has contributed to updating listing decisions and preserving historic building's scale,

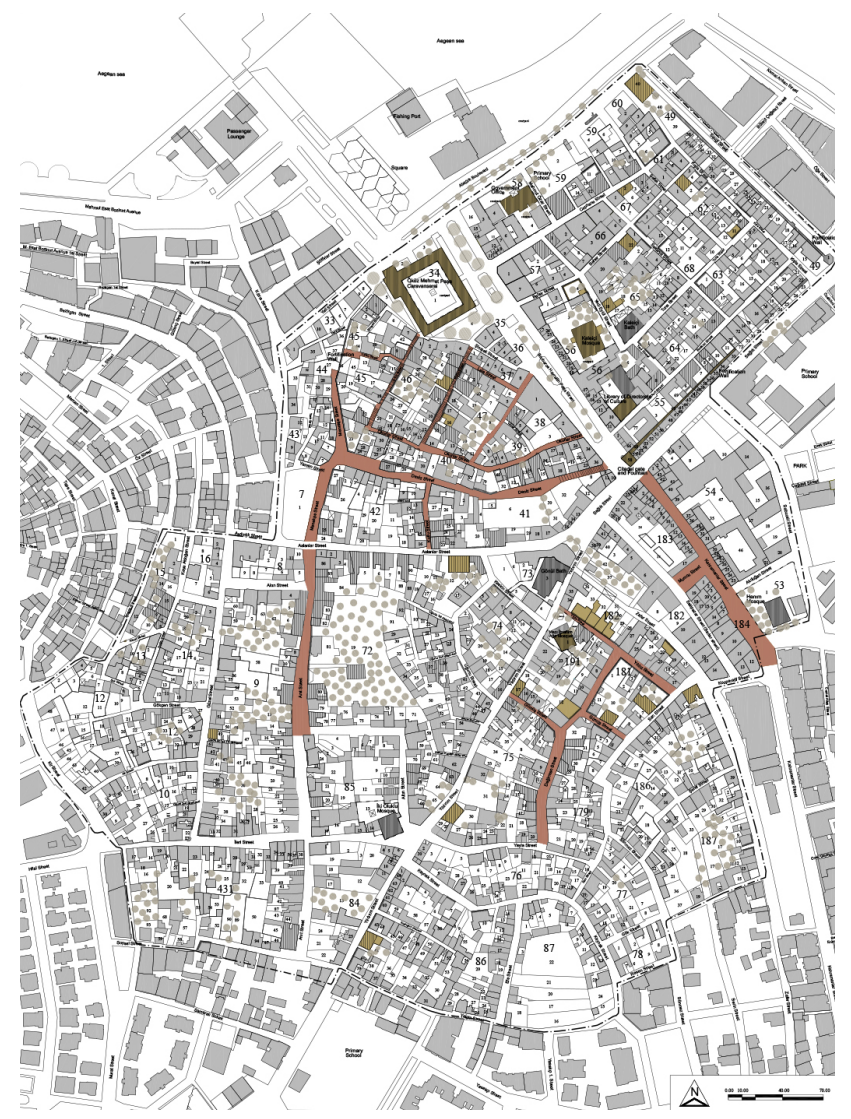

Fig. 15 Implementations between 2013 and 2016 (Yönetken, 2018) form and façade order. However, it has not been determined in sustaining the wholeness of lot-building relations. The increase in lot coverage ratios of especially the public buildings, which are listed, are regrettable (Fig. 16, Yönetken, 2018). Similarly, transparency of construction techniques and material is not achieved since renewal is an approved intervention type.

\section{Conclusion}

The local lifestyle in the small fishing town of Kuşadası has been converted into a modern vacation resort with the effect of mass tourism. The authenticity of cultural traditions has been negatively affected. Conservation implementations generally focus on a single building scale, whereas urban scale implementations are limited in number. The visual authenticity of historic buildings is threatened by the excessive renewal of building elements, and changes in construction techniques and materials. There is an overall lack of monitoring in the studied cultural

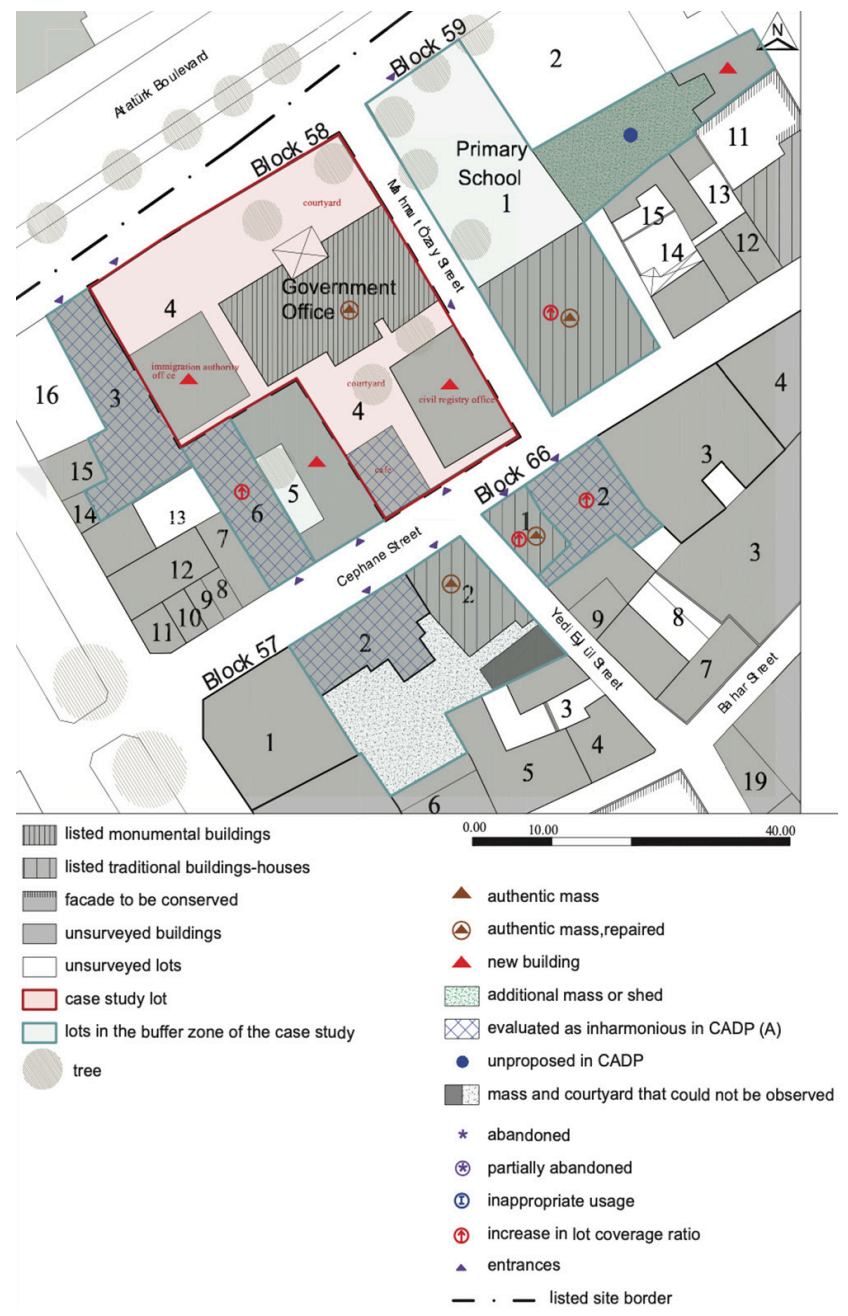

Fig. 16 Survey of the government office, plan (Yönetken, 2018) 
landscape; so, comprehensive restorations are undertaken, giving way to renewals and alterations. New buildings at the buffer zones of cultural heritage have been often subject to discussions in the Regional Commission for their enhancement. However, many of these were already evaluated as inharmonious in the conservation plan. Consequently, there is a contradiction between the plan and the decisions of the Regional Commission. The conservation plan has not been updated since 1994. This has necessitated more effort from all actors in the processing

\section{References}

Atilla, N. (2002) "İzmir Demiryolları" (İzmir Railways), İzmir Büyükşehir Belediyesi Kültür Yayınları, Izmir, Turkey. (in Turkish)

Apple Maps "Kuşadası", [online] Available at: https://www.apple.com/tr/ maps/ [Accessed: 03 December 2018]

Arslan, A. (1960s) "Kaleiçi Mosque as viewed from west", [black and white photography] Kuşadası Historic Site, Studio AC Archive, Kuşadası, Aydın, Turkey.

Arslan, A. (1970s) "Shops on Kahramanlar Street", [black and white photography] Kuşadası Historic Site, Studio AC Archive, Kuşadası, Aydin, Turkey.

Bektaş, C. (1993) "Kuşadası Evleri" (Kuşadası Houses), Bektaş Mimarlık Mühendislik A.Ş. Yayınları, Istanbul, Turkey. (in Turkish)

Çobanoğlu, A. V. (2007) "Öküz Mehmet Paşa Külliyesi" (Social Complex of Öküz Mehmet Paşa), TDV İslam Ansiklopedisi, [online] Available at: https://islamansiklopedisi.org.tr/okuz-mehmed-pasakulliyesi--aydin [Accessed: 31 March 2021] (in Turkish)

Faroqhi, S. (1993) "Osmanlı'da Kentler ve Kentliler: Kent Mekanında Ticaret, Zanaat ve G1da Üretimi 1550-1650" (Ottoman Cities and Citizens: Trade, Craft and Food Production in Urban Space), Gökhan Matbaacılık, Istanbul, Turkey. (in Turkish)

Gök, L. (2017) "Conservation of Cultural Heritage in Turkey: Development of Legal Rules and Institutions", [pdf] In: Historical Perspective of Heritage Legislation: Balance between Laws and Values, Conference Proceedings, Tallinn, Estonia, pp. 39-42. Available at: http://openarchive.icomos. org/id/eprint/2075/1/2018_04_24_1666_kogumik-9-TAMERG\%C3\%96K.pdf [Accessed: 23 March 2021]

Google Maps "Kuşadası Kaleiçi", [online] Available at: https://www.google. com/maps/search/kuşadası+kaleiç/@37.8573278,27.250324,15.65z [Accessed: 12 October 2021]

Güçhan, N. Ş., Kurul, E. (2009) "A History of the Development of Conservation Measures in Turkey: From the Mid 19th Century until 2004", METU Journal of the Faculty of Architecture, 26(2), pp. 19-44

http://doi.org/10.4305/metu.jfa.2009.2.2

ICOMOS (1987) "Charter for the Conservation of Historic Towns and Urban Areas (Washington Charter)", ICOMOS, Washington, DC, USA.

ICOMOS (1994) "The Nara Document on Authenticity", ICOMOS, Nara, Japan.

ICOMOS (2008) "Quebec Declaration on the Preservation of the Spirit of Place", ICOMOS, Quebec, Canada. of the related conservation activities. A management plan for the Kuşadası cultural landscape should be prepared, and the current conservation plan should be revised.

\section{Acknowledgement}

The authors are thankful to the Republic of Turkey Ministry of Culture and Tourism, General Directorate of Cultural Heritage and Museums; Aydın Regional Commission on the Conservation of Cultural Property, and Kuşadası Municipality for providing documents.

ICOMOS (2011) "The Valetta Principles for the Safeguarding and Management of Historic Cities, Towns and Urban Areas", ICOMOS, Paris, France.

ICOMOS (2013) "The Australia ICOMOS Charter for Places of Cultural Significance (Burra Charter)", Australia ICOMOS, Burwood, Australia.

ICOMOS (2017) "Delhi Declaration on Heritage and Democracy", ICOMOS, New Delhi, India.

Ijas, A., Kuitunen, T., Kimmo, J. (2010) "Developing the RIAM method (rapid impact assessment matrix) in the context of impact significance assessment", Environmental Ipact Assessment Review, 30(2), pp. 82-89.

https://doi.org/10.1016/j.eiar.2009.05.009

Kiel, M. (2000) "Kuşadası: Genoese Colonial Town of the 1300s or Ottoman Creation of the $17^{\text {th }}$ Century?", In: Ciépo XIV. Sempozyumu Bildirileri, Türk Tarih Kurumu, Ankara, Turkey, pp. $403-415$.

Kutluay, S. (1994) "Kuşadası Koruma Amaçlı İmar Planı" (Conservation Development Plan for Kuşadası Historic Urban Site), Kuşadası Municipality Collection, A.266, Archive of Kuşadası Municipality, Aydın, Turkey.

Madran, E., Özgönül, N. (2005) "Kültürel ve Doğal Değerlerin Korunması" (Conservation of Cultural and Natural Values), TMMOB Mimarlar Odası, Ankara, Turkey. (in Turkish)

Map Stack "Kuşadası", [online] Available at: https://mapstack.stamen.com/ edit.html\#terrain/14/37.8506/27.2602 [Accessed: 22 March 2017]

Pastakia, C. M. R., Jensen, A. (1998) "The Rapid Impact Assessment Matrix (RIAM) for EIA", Environmental Impact Assessment Review, 18(5), pp. 461-482.

https://doi.org/10.1016/S0195-9255(98)00018-3

Pekak, M. S., Aydın, S. (1998) "Selçuk ve Çevresinde Osmanlı İdaresindeki Gayri Müslim Tebaanın İmar Faaliyetleri" (The Construction Activities of the Non-Muslim Population under the Rule of the Ottomans in Selçuk and its Vicinity), Hacettepe Üniversitesi Edebiyat Fakültesi Dergisi, 15(2), pp. 125-155. [online] Available at: https://dergipark.org.tr/tr/download/articlefile/611261 [Accessed: 31 March 2021] (in Turkish)

Regional Commission (1976a) "A-266, Plan Decisions on Kuşadasi Historic Urban Site and Conservation Areas", Decision Date: 11 December 1976, Aydın Regional Commission on the Conservation of Cultural Property Collection, Archive of Aydin Regional Commission on the Conservation of Cultural Property, Aydın, Turkey. 
Regional Commission (1976b) "Listing Decisions on Kuşadası Listed Urban Site", Decision Date: 11.12.1976, Immovable Old Antiquities and Monuments Supreme Council, Archive of Aydın Regional Commission on the Conservation of Cultural Property, Aydın, Turkey.

Regional Commission (1978) "Listing Decisions on Kuşadası Listed Urban Site", Decision Date: 21.3.1978, Immovable Old Antiquities and Monuments Supreme Council, Archive of Aydın Regional Commission on the Conservation of Cultural Property, Aydın, Turkey.

Regional Commission (1986) "Listing Decisions on Kuşadasi Historic Urban Site", Decision Date: 06 January 1986, Aydın Regional Commission on the Conservation of Cultural Property Collection, Archive of Aydin Regional Commission on the Conservation of Cultural Property, Aydın, Turkey.

Regional Commission (1987) "3495, Listing Decisions on Kuşadasi Historic Urban Site", Decision Date: 03 July 1987, Aydın Regional Commission on the Conservation of Cultural Property Collection, Archive of Aydın Regional Commission on the Conservation of Cultural Property, Aydın, Turkey.

Regional Commission (1994) "Listing Decisions on Kuşadasi Historic Urban Site", Decision Date: 19.1.1994, Aydın Regional Commission on the Conservation of Cultural Property Collection, Archive of Aydın Regional Commission on the Conservation of Cultural Property, Aydın, Turkey.

Regional Commission (1999) "3779, Listing Decisions on Kuşadasi Historic Urban Site", Decision Date: 18 January 1999, Aydın Regional Commission on the Conservation of Cultural Property Collection, Archive of Aydin Regional Commission on the Conservation of Cultural Property, Aydın, Turkey.

Regional Commission (2008) "Listing Decisions on Kuşadasi Historic Urban Site", Decision Date: 23 March 2008, Aydın Regional Commission on the Conservation of Cultural Property Collection, Archive of Aydın Regional Commission on the Conservation of Cultural Property, Aydın, Turkey.

Republic of Turkey (1983) "2863, Kültür ve Tabiat Varlıklarını Koruma Kanunu" (2863, Conservation of Cultural and Natural Heritage Act), T.C. Resmi Gazete, 22(18113), pp. 5879-5900-1, Article numbers: 3.10, 10, 12, 57.g. [online] Available at: https://www.mevzuat.gov.tr/ MevzuatMetin/1.5.2863.pdf [Accessed: 22 March 2021] (in Turkish) Republic of Turkey (1985) "İmar Kanunu" (Law of Public Improvements), T.C. Resmi Gazete, 24(18749), pp. 6677-6698, Article numbers: 21, 23. [online] Available at: https://www.mevzuat.gov.tr/ MevzuatMetin/1.5.3194.pdf [Accessed: 20 May 2021] (in Turkish)

Republic of Turkey (1999) "660, Taşınmaz Kültür Varlıklarının Gruplandırılması, Bakım ve Onarımı" (660, Grouping of Immovable Cultural Assets, their Maintenance and Repair), DecisionDate: 05 November 1999, Republic of Turkey, Ministry of Culture and Tourism, Higher Council for Conservation of Cultural Property Collection, Archive of Higher Council for Conservation of Cultural Property, Ankara, Turkey. [online] Available at: http://teftis.kulturturizm.gov.tr/TR-14330/660nolu-ilke-karari-tasinmaz-kultur-varliklarinin-grup-.html [Accessed: 11 February 2018] (in Turkish)
Republic of Turkey (2005) "Kültür ve Tabiat Varlıklarını Koruma Kanunu Kapsamındaki Kültür Varlıklarının Rölöve, Restorasyon, Restitüsyon Projeleri, Sokak Sağlıklaştırma, Çevre Düzenleme Projeleri ve Bunların Uygulamaları ile Değerlendirme, Muhafaza, Nakil İşleri ve Kazı Çalışmalarına İlişkin Mal ve Hizmet Alımlarına Dair Yönetmelik" (Guideline for Purchasing of Commodity and Service regarding Measured Survey, Restoration, Restitution Projects; Street Rehabilitation and Environmental Organization Projects; and related Implementation, Evaluation, Storage, Transportation and Excavation of Cultural Property), Republic of Turkey, Ministry of Culture and Tourism. [online] Available at: https://www.resmigazete.gov.tr/eskiler/2005/06/20050618-4.htm [Accessed: 20 March 2021] (in Turkish)

Republic of Turkey (2021a) "Taşınmaz Kültür Varlıklarının Korunmasına ait Katkı Payına dair Yönetmelik" (Regulation regarding Contribution Margin for Conservation of Immovable Cultural Property), Republic of Turkey, Ministry of Culture and Tourism, Directorate of Inspection Commission, Ankara, Turkey. [online] Available at: https://teftis.ktb.gov.tr/TR-264434/tasinmazkultur-varliklarinin-korunmasina-ait-katki-pay-.html [Accessed: 23 March 2021] (in Turkish)

Republic of Turkey (2021b) "Birimlerin Görevleri ve Tanımları - Planlama ve Koordinasyon Müdürlüğ̈̈" (Responsibilities and Definitions of the Offices - Directorate of Planning and Coordination), Republic of Turkey, Ministry of Culture and Tourism, General Directorate of Foundations, Ankara, Turkey. [online] Available at: https://www. vgm.gov.tr/kurumsal/teskilat-yapisi/birimlerin-gorev-ve-tanimlari [Accessed: 23 March 2021] (in Turkish)

Republic of Turkey (2021c) "Kültür Varlıklarını Koruma Yüksek Kurulu" (Higher Council for Conservation of Cultural Property), Republic of Turkey, Ministry of Culture and Tourism, General Directorate of Cultural Heritage and Museum, Ankara, Turkey. [online] Available at: https://kvmgm.ktb.gov.tr/TR-44347/kultur-varliklarini-korumayuksek-kurulu.html [Accessed: 23 March 2021] (in Turkish)

Republic of Turkey (2021d) "Koruma Bölge Kurullarının Görevi ve Oluşumu" (Responsibilities and Structuring of Regional Commissions on the Conservation of Cultural Property), Republic of Turkey, Ministry of Culture and Tourism, General Directorate of Cultural Heritage and Museum, Ankara, Turkey. [online] Available at: https:// korumakurullari.ktb.gov.tr/TR-89185/koruma-bolge-kurullariningorevi-ve-olusumu.html [Accessed: 23 March 2021] (in Turkish)

Sağdıç, O. (1988) "Kuşadası: Ephesus Didyma, Miletus, Priene, Heraclea, Magnedia, Nysa, Aphrodisias, Hierapolis", Santur, Ankara, Turkey.

Sarupria, M., Manjare, S. D., Girap, M. (2019) "Environmental impact assessment studies for mining area in Goa, India, using the new approach", Environmental Monitoring and Assessment, 191, Article number: 18 https://doi.org/10.1007/s10661-018-7135-z

Teker, İ. (2013) "Re-reading of the Conservation Activities in the Historic City of Gaziantep in the 2000s Through Conservation Council Decisions", MS Dissertation, Middle East Technical University. 
UNESCO (2019) "The Operational Guidelines for the Implementation of the World Heritage Convention", United Nations, Educational, Scientific and Cultural Organization, UNESCO World Heritage Center, Paris, France. [online] Available at: https://whc.unesco.org/ en/guidelines/ [Accessed: 21 March 2021]

Üstünkök, O. (1989) "Ten Years with Seventeen-Ten: A Decade in the Conservation of Traditional Vernacular Houses 1973-1983", [pdf] METU Journal of the Faculty of Architecture, 9(2), pp. 117-124. Available at: http://jfa.arch.metu.edu.tr/archive/0258-5316/1989/ cilt09/sayi_2/117-124.pdf [Accessed: 31 March 2021]
Yıldırım, A. E. (2011) "Kentsel Koruma Projelerinde Aktörlerin Örgütlenmesi: Gaziantep, Kuşadası ve Mudurnu Örnekleri Üzerinden Türkiye'nin Tarihi Kent Dokularında Uygulanabilir Örgütlenme Modellerine Yönelik Bir Araştırma" (Organisation of Actors in Urban Conservation Projects: an Investigation regarding Organisation Models with Implementation Potential in Historic Urban Sites of Turkey, the Cases of Gaziantep, Kuşadası and Mudurnu), Doctoral Dissertation, Ankara University. (in Turkish) Yönetken, E. E. (2018) "Evaluation of current conservation activities in Kuşadası urban site", MS Dissertation, Izmir Institute of Technology. 